\title{
First-Line Molecular Genetic Evaluation of Autosomal Recessive Non-Syndromic Hearing Loss
}

\author{
Berk Özyılmaz (1), Gül Caner Mercan² (1), Özgür Kırbıyık ${ }^{1}$ (D), Taha Reşid Özdemir ${ }^{1}$ (), \\ Samira Özkara ${ }^{2}$ (D), Özge Özer Kaya ${ }^{1}$ (D), Yaşar Bekir Kutbay ${ }^{1}$ (D), Kadri Murat Erdoğan ${ }^{1}$ (D), \\ Merve Saka Güvenç ${ }^{1}$ (D), Altuğ Koç ${ }^{1}$ (1) \\ Original Investigation $\quad{ }^{1}$ Genetic Diagnosis Center, University of Health Sciences, Tepecik Training and Research Hospital, İzmir, Turkey \\ ${ }^{2}$ Department of Otolaryngology, University of Health Sciences, Tepecik Training and Research Hospital, İzmir, Turkey
}

Abstract

ORCID IDs of the authors: B.0. 0000-0003-2654-3698; G.C.M. 0000-0002-0968-9305; O.K. 0000-0003-1333-2007; T.R.0̈.0000-0003-4870-6945; S.0̈.0000-0003-2257-2969; Ö.0.K. 0000-0001-6731-2461; Y.B.K. 0000-0002-9006-5072; K.M.E. 0000-0003-0097-1424; M.S.G. 0000-0001-8842-0381; A.K. 0000-0002-8366-6806.

Cite this article as: Özylmaz B, Caner Mercan G, Kırbıyık Ö, Özdemir TR, Özkara S, Özer Kaya $0 ̈$, et al. First-Line Molecular Genetic Evaluation of Autosomal Recessive Non-Syndromic Hearing Loss. Turk Arch Otorhinolaryngol 2019; 57(3): 140-8.

\section{Corresponding Author:}

Berk Özyılmaz; drberk@gmail.com

Received Date: 31.03.2019

Accepted Date: 20.06.2019

Content of this journal is licensed under a Creative Commons Attribution 4.0 International License. Available online at www.turkarchotolaryngol.net
Objective: The aim of this study is to investigate the efficiency of a first-line molecular genetic evaluation approach, in children with deafness.

Methods: Patients who were found to have sensorineural hearing loss by age-appropriate audiological tests were selected for the molecular genetic evaluation. The molecular genetic evaluation was carried out with GJB2 gene sequence analysis and mtDNA m.1555A $>\mathrm{G}$ mutation Restriction Fragment Length Polymorphism (RFLP) analysis. Additionally, in a small group of patients, hearing loss Multiplex Ligation-dependent Probe Amplification (MLPA) analysis was done out to identify the possible role of copy number changes.

Results: In this Turkish cohort, which included 104 index patients and 78 relatives, 33 (31.7\%) had Pathogenic/Likely Pathogenic variants. One or more GJB2 sequence variants were identified in $46(44.1 \%)$ of the
104 index patients. The homozygous c. $35 \mathrm{delG}$ mutation by itself explained the etiology in $24 \%$ of our ARSNHL group. In one (5\%) of the 20 patients of MLPA group, a hemizygous deletion in POU3F4 gene was detected.

Conclusion: In our Turkish cohort, we applied a first-line molecular genetic evaluation approach using GJB2 gene sequence analysis and mtDNA m.1555A $>$ G RFLP analysis. This approach revealed the genetic etiology of $44.1 \%$ of our index patients. Additionaly, the results of hearing loss MLPA analysis revealed the limited role of copy number changes in this patient group. Furthermore, with a detailed genotype-phenotype association workup, 2 rare cases of Deafness with Palmoplantar Hyperkeratosis and Keratitis-Ichthyosis-Deafness syndrome were reported.

Keywords: Deafness, hearing loss, genetics, GJB2

\section{Introduction}

Hearing loss (HL) or hearing impairment, is a partial or total inability to hear. Hearing loss may be mild, moderate, moderate-to-severe, severe, or profound. Profound or total loss of hearing is defined as deafness. According to the World Health Organization (WHO), 466 million people in the world are affected by "disabling hearing loss" (more than $5 \%$ of the world's population) and 34 million (7.2\%) of these are children (1). The prevalence of disabling hearing loss in children is $1.7 \%$ worldwide and $0.9 \%$ in our region (2). Hearing loss in children can be classified by type (conductive/sensorineural $/ \mathrm{mixed} /$ central), by degree (mild/moderate/moderate-to-severe/severe/profound), by configuration (high-frequency/ low-frequency, bilateral/unilateral, symmetrical/ asymmetrical, progressive/sudden, fluctuating/stable), by time of onset (prenatal/neonatal/postnatal), by etiology (congenital [genetic/non-genetic], acquired), and in terms of its influence on speech development (prelingual/postlingual) $(3,4)$.

Hearing loss can be due to environmental factors, genetic factors, or the combination of both. In developed countries, genetic factors are the leading cause of childhood HL. While 30\% of all genetic HL cases are syndromic (SHL), the remaining $70 \%$ of the cases, where $\mathrm{HL}$ is the only feature, are non-syndromic (NSHL). The genetic causes of NSHL are generally associated with mutations in single genes (5). To date, more than 100 genes have been associated 
with non-syndromic hearing loss (6). The NSHL is a heterogeneous group of disorders since different mutations in the same gene can cause different types of hearing loss. Furthermore, some genes are associated with both the syndromic and the non-syndromic forms of HL (7). Autosomal-recessive NSHL (ARNSHL) accounts for 80\%, autosomal dominant (ADNSHL) for 20\%, X-linked for $1 \%$ of all NSHL while mitochondrial is rare $(<1 \%)$. Most ARNSHL cases are prelingual, severe-to-profound, whereas ADNSHL cases are often postlingual and progressive (1).

The nomenclature for NSHL is defined by several abbreviations. "DFN" is used to indicate Non-syndromic deafness loci; the following A, B or X letters are added for the mode of inheritance (DFNA: autosomal dominant; DFNB: autosomal recessive; DFNX: X-linked) and the last number is for the gene in the order of gene mapping or discovery (8).

About $50 \%$ of the ARNSHL cases are associated with the DFNB1 locus. The GJB2 gene, which encodes the gap junction protein connexin 26 (Cx26), is the primarily associated gene for the DFNB1 locus. Mutations in another connexin gene, GJB6 (connexin 30/Cx30), can also cause DFNB1. The importance of connexin proteins in hearing loss comes from the role these proteins play in forming channels called gap junctions. The Cx26 gap junctions are formed among non-sensory epithelial cells and connective tissue cells, serving as a structural basis for recycling endolymphatic potassium ions (9). It was hypothesized that nonfunctional gap junctions cause elevated extracellular potassium concentration, extracellular accumulation of glutamate and the apoptosis of cochlear epithelial cells and outer hair cells (9).

Although mtDNA mutations are generally responsible for less than $1 \%$ of the disease, $\mathrm{m} .1555 \mathrm{~A}>\mathrm{G}$ mutation found in the $12 \mathrm{~S}$ RNA gene of mitochondria is more common in the Far East countries. Studies conducted with Turkish patients have shown that it contributes by $1.8 \%$ (8).

In patients with hearing loss diagnostic approach starts with family history and physical examination. It is important to obtain at least three generations of family history and pedigree. This will give a clue of the type of inheritance, and as well help to identify the other affected individuals in the family. Because of the variable expressivity, it is necessary to be cautious against the additional symptoms associated with syndromic hearing loss that can manifest very mildly due to variable expression (10).

Audiometric testing is important in determining whether the hearing loss is unilateral or bilateral, and in determining which frequencies are more prominently lost. The physical examination, the audiologic phenotype, and the patient's ethnicity are the most critical data that guide the selection of molecular genetic testing. It is controversial if genetic testing should be offered to non-syndromic children with unilateral hearing loss, in initial workup (11).
According to the consensus recommendations released by the International Pediatric Otolaryngology Group (IPOG), in the molecular genetic evaluation of children with bilateral sensorineural hearing loss, single gene analysis (GJB2/GJB6) or comprehensive genetic testing (next-generation sequencing gene panels) may be preferred, depending on the patient's audiometric phenotype, ethnic origin and availability of tests (9).

IPOG emphasizes the importance of ethnic origin in determining the genetic testing strategy. As an example to this, even if $G J B 6$ has been shown to contribute significantly to the etiology of the DFNB1 group, many studies have shown that GJB6 does not play a significant role in the Turkish population $(10,11)$. Furthermore, although mtDNA mutations are very rare $(<1 \%)$ in the general population, they reach a frequency of $1.8 \%$ in the Turkish population (12).

In this report, we applied a first-line molecular genetic evaluation approach using GJB2 gene sequence analysis, mtDNA m.1555A $>\mathrm{G}$ mutation RFLP analysis in 182 Turkish patients suspected of ARNSHL. We evaluated the diagnostic rates of our approach and investigated variant frequencies associated with GJB2 in Turkey. The association between genotype and phenotypes was also analyzed.

\section{Methods}

\section{Patient selection}

The study was approved by the University of Health Sciences, Tepecik Training and Research Hospital, Ethics Committee (2019/2-18). Written informed consent was obtained from the parents or guardians of the children.

Patients were mostly referred by the Child Hearing Assessment Center of Tepecik Training and Research Hospital. Audiometric tests of patients were also performed in this center.

Patients who were found to have sensorineural hearing loss and no additional findings suggesting a syndromic hearing loss were included in the molecular genetic evaluation.

\section{Audiological testing}

Hearing thresholds were determined by age-appropriate audiological tests. Patients under three years of age were tested by auditory brainstem audiometry (Navigator pro, Bio-Logic Systems Corp, Mundelein, IL, USA), and when possible by tonal audiometry with warble tones presented through TDH 39 supra-aural headphones by means of a clinical audiometer (Madsen TM, Orbiter 922, GN Otometrics, Copenhagen, Denmark). In order to exclude any auditory neuropathy spectrum disorder, otoacoustic emissions were also tested by Otodynamics ILO 88 OAE system (Otodynamics Inc., Hatfield, Herts, UK). The degree of hearing loss was determined based on The American Speech-Language-Hearing Association (ASHA) criteria (4). 


\section{GJB2 sequence analysis}

Genomic DNA was extracted from peripheral blood samples according to the manufacturer's protocols. The entire coding and flanking region of GJB2 were amplified by polymerase chain reaction (PCR) in two overlapping segments:

Cx26 1F: 5'-TGT AAA ACG ACG GCC AGT CAT TCG TCT TTT CCA GAG CA-3'

\section{Cx26 2R: 5'-CAG GAA ACA GCT ATG ACC AGC CTT CGA TGC GGA CCT-3'}

\section{Cx26 3F: 5'-TGT AAA ACG ACG GCC AGT ACC GGA GAC ATG AGA AGA AG-3'}

\section{Cx26 4R: 5'-CAG GAA ACA GCT ATG ACC GTT GCA TTT AAG GTC AGA ATC-3'}

Polymerase chain reaction conditions were as follows: $100 \mathrm{ng}$ of genomic DNA was amplified in a $10 \mu \mathrm{l}$ reaction volume. An initial denaturation step of $10 \mathrm{~min}$ at $95^{\circ} \mathrm{C}$ was followed by 35 cycles of $95^{\circ} \mathrm{C}$ for 30 secs, $60^{\circ} \mathrm{C}$ for 45 secs and $72^{\circ} \mathrm{C}$ for one min. And one final cycle of $72^{\circ} \mathrm{C}$ for $7 \mathrm{~min}$. PCR products were purified (ExoSAP-IT, Thermo Fisher Scientific Inc., MA, USA) prior to cycle sequencing. For sequencing, the ABI PRISM Big Dye Primer v3.0 Cycle Sequencing Ready Reaction kit was used (Big Dye Primer Cycle Sequencing Ready Reaction Kit, Applied Biosystems Inc., CA, USA) and the reaction products were analyzed on an ABI 3500 (ABI 3500 Genetic Analyzer, Applied Biosystems Inc., CA, USA) automated sequencer. Sequence chromatograms were obtained using SeqScape software (Seqscape V2, Applied Biosystems Inc., CA, USA).

Detected variants were analyzed using the ClinVar database (12) and the recommendations for variant interpretation by the American College of Medical Genetics and Genomics (ACMG) $(13,14)$.

\section{mtDNA A1555G mutation analysis}

To detect $\mathrm{A} 1555 \mathrm{G}$ mtDNA mutation, the PCR was used to amplify the genomic region covering the mutation. To discriminate wild type and mutant sequences, a restriction endonuclease reaction was used. Digestion products were then electrophoresed through $12 \%$ agarose gels and fragment sizes visualized by autoradiography. To identify the $\mathrm{A} 1555 \mathrm{G}$ mutation, a 566 bp PCR product was digested with HaeIII enzyme (HaeIII, New England Biolabs, Ipswich, MA, USA). If the A to G mutation at position 1555 was present, a $111 \mathrm{bp}$ fragment was cleaved into 91 and $20 \mathrm{bp}$ fragments.

Hearing loss Multiplex Ligation-dependent Probe Amplification (MLPA) analysis

To identify copy number changes in a small group of patients (20 patients), P163 probemix (SALSA MLPA P163 GJBWFS1 Probemix, MRC-Holland BV, Amsterdam, the Netherlands) was used. The MLPA probe mix was containing probes for all exons of GJB2 and GJB6 genes, exon 1 and upstream of the POU3F4 gene and eight exons of the WFS1 gene. The PCR products obtained as a result of MLPA reaction were run on the Applied Biosystems 3500 capillary electrophoresis device. As a result of the process, peak images and peak areas of the probes of each sample were obtained in the CEQ program. Excel based Coffalyser (Coffalyser, MRC-Holland BV, Amsterdam, the Netherlands) program was used for analysis.

\section{Results}

\section{Characteristics of the patients}

The patients' audiometric testing results varied from bilateral mild hearing loss to bilateral profound hearing loss. Of the 25 patients with homozygous c. $35 \mathrm{delG}$ mutation, 21 were evaluated by audiometric testing. Of these 21 patients, 13 (62\%) had profound hearing loss, seven (33\%) had moderately severe/severe hearing loss and one (5\%) had moderate hearing loss. While 12 of these 21 patients were male, nine were female.

\section{Sequence variants detected by GJB2 sequence analysis}

A total number of 182 samples (104 index patients and their 78 relatives) were analyzed by GJB2 sequencing analysis.

One or more GJB2 sequence variants were detected in 46 (44.1\%) of the 104 index patients. Of these 46 patients, 33 (31.7\%) had pathogenic/likely pathogenic variants, six (5.7\%) had benign variants and seven (6.7\%) had variants of unknown significance (VUS).

In 46 (44.2\%) patients with sequence variants, homozygous c.35delG (p.Gly12ValfsTer2) was the most frequent variant, detected in $25(24 \%)$ index patients. Other frequent variants were c. $457 \mathrm{G}>\mathrm{A}$ (p.Val153Ile), c.487A>G (p.Met163Val) and c.478G $>$ A (p.Gly160Ser), detected in five (4.8\%), three (2.8\%) and two (1.9\%) index patients, respectively.

\section{Frequent variants c.35delG (p.Gly12ValfsTer2)}

In 25 of the index patients, homozygous c. $35 \mathrm{delG}$ mutation was detected. This mutation alone was explaining $24 \%$ of the etiology of our ARSNHL group. Patients with this homozygous mutation were mainly suffering from moderate to profound hearing loss.

c. $457 \mathrm{G}>\mathrm{A}$ (p.Val153Ile)

In five of the index patients, there was a heterozygous c. $457 \mathrm{G}>\mathrm{A}$ variant. This variant was listed as benign in the ClinVar database.

c. $487 \mathrm{~A}>\mathrm{G}$ (p.Met163Val)

A heterozygous c. $487 \mathrm{G}>\mathrm{A}$ variant was detected in three index patients and in two unaffected mothers. This variant was interpreted as VUS (PM1, PP2, and PP3) according to the ACMG guidelines and it was listed as VUS in the ClinVar database. 
c. $478 \mathrm{G}>\mathrm{A}(\mathrm{p} . \mathrm{Gly} 160 \mathrm{Ser})$

Two sibs (Patients \#11 and \#12) were detected to carry heterozygous c. $478 \mathrm{G}>\mathrm{A}$ variant. This variant was listed as "conflicting interpretations of pathogenicity" in the ClinVar database and it was interpreted as VUS (PM1, PP2, and PP3) according to the ACMG guidelines. The variant was associated with autosomal recessive and autosomal dominant SNHL.

\section{Rare variants}

c. $670 \mathrm{~A}>\mathrm{C}$ (p.Lys224Gln)

A homozygous c. $670 \mathrm{~A}>\mathrm{C}$ variant was detected in patient \#14. Her parents were heterozygous for the variant. This variant was interpreted as VUS (PP2 and PP3) according to the ACMG guidelines and it was listed as VUS in the ClinVar database.

c.511G >A (p.Ala171Thr)

Patient \#38 was carrying the c.511G>A variant in heterozygous form. The variant was interpreted as VUS (PM1 and PP2) according to the ACMG guidelines and it was listed as VUS in the ClinVar database.

\section{c.5_9delinsCAT (p.Asp2AlafsTer45)}

In patient \#157 a heterozygous c.5_9delinsCAT variant was detected. The patient was consulted for hearing loss and palmoplantar hyperkeratosis. This variant was causing a frameshift in GJB2 gene translation. The variant was interpreted as likely pathogenic (PVS1 and PP2) according to the ACMG guidelines and it was not listed in databases. We suggest this variant as a novel mutation.

c.314_329del (p.Lys105ArgfsTer2)

Patient \#163 was carrying the c.314_329del variant in the heterozygous state. This was a frameshift variant. The variant was interpreted as pathogenic (PVS1, PM1, PM2, and PP5) according to the ACMG guidelines and it was listed as pathogenic in the ClinVar database.

c.263C > T (p.Ala88Val)

The variant was detected in patient \#177 in the heterozygous state and it was listed as pathogenic in the ClinVar database. The patient was a 1-month-old girl with dysmorphic features (frontal bossing and down-slanting palpebral fissures), congenital ichthyosis, keratoconjunctivitis sicca in eyes and nail dystrophy. The patient was diagnosed as Keratitis-Ichthyosis-Deafness syndrome (KID).

c.551G>C (p.Arg184Pro)

Patient \#135 was carrying the c.551G>C variant in the heterozygous state. The variant was interpreted as VUS (PM2, PP2, PP3, and PP5) according to the ACMG guidelines; however, it was listed as pathogenic in the ClinVar database.

\section{Compound heterozygous variants \\ c. $35 \mathrm{delG} / \mathrm{c} .47 \mathrm{~A}>\mathrm{G}$}

Patient \#18 was carrying c. 35 delG/ c. $47 \mathrm{~A}>\mathrm{G}$ variants in the compound heterozygous state. Both variants were known as pathogenic mutations. Both parents were carrying each of the variants in the heterozygous state.

\section{c.35delG/ c. $269 \mathrm{~T}>\mathrm{C}$}

The c.35delG/ c.269T >C variants were detected in patient \#43 in the compound heterozygous state. The c. $35 \mathrm{delG}$ was a known pathogenic mutation. c.269T>C was listed pathogenic in the ClinVar database.

c. $35 \mathrm{delG} /$ c. $71 \mathrm{G}>\mathrm{A}$

Two sibs (\#166 and \#167) were carrying the c.35delG/ c.71G>A variants in the compound heterozygous state. The c. $35 \mathrm{delG}$ was a known pathogenic mutation. The c. $71 \mathrm{G}>\mathrm{A}$ was a frameshift variant with Pathogenic records in the ClinVar database.

\section{c. $79 \mathrm{G}>\mathrm{A} /$ c. $341 \mathrm{~A}>\mathrm{G}$}

Patient \#2 and her unaffected mother were carrying c.79G>A/ c. $341 \mathrm{~A}>\mathrm{G}$ variants in compound heterozygous form (-cis state). Both variants were listed as benign in ClinVar.

\section{mtDNA A1555G mutation analysis}

No mtDNA A1555G mutation was detected in the index patient group (104 patients).

\section{Hearing loss MLPA analysis}

In 58 patients no variants were detected. Twenty of the $58 \mathrm{pa}^{-}$ tient were selected for MLPA P163 GJB-WFS1 analysis. In one (5\%) of the 20 patients, a hemizygous deletion in POU3F4 gene was detected.

Audiometry results and molecular genetic findings are summarized in Table 1.

\section{Discussion}

A 70\% of genetic HL, is NSHL. The genetic causes of NSHL are generally associated with mutations in single genes. According to the consensus recommendations released by IPOG, in the molecular genetic evaluation of NSHL, selection of the approach (GJB2/GJB6 single gene analysis vs multigene next-generation sequencing panels) should depend on the patient's audiometric phenotype, ethnic origin, and availability of the tests. As for the Turkish population, several studies showed that GJB6 does not play a significant role in the Turkish population (10, 11). Thus, we applied a first-line molecular genetic evaluation approach using GJB2 gene sequence analysis and mtDNA m.1555A $>$ G RFLP analysis in patients suspected of ARNSHL. We also investigated the role of copy number changes by MLPA analysis in a subgroup of patients in which GJB2 mutation was not detected. 
Özyılmaz et al.

144 Genetics of Non-Syndromic Hearing Loss

Turk Arch Otorhinolaryngol 2019; 57(3): 140-8

Table 1. Patients' age, degree of hearing loss, molecular genetic findings and results of family investigations

\begin{tabular}{|c|c|c|c|c|c|c|c|c|c|}
\hline Patient\# & Family\# & Age & $\begin{array}{l}\text { Degree of } \\
\text { SNHL }\end{array}$ & $\begin{array}{l}\text { Cochlear } \\
\text { implant }\end{array}$ & $\begin{array}{l}\text { GJB2 } \\
\text { variant }\end{array}$ & $\begin{array}{l}\text { Protein } \\
\text { Change }\end{array}$ & Status & $\begin{array}{l}\text { Family } \\
\text { Investigations }\end{array}$ & $\begin{array}{l}\text { Variant Interpret. } \\
\text { (ACMG/ClinVar) }\end{array}$ \\
\hline & & & & & c.35delG & & & & \\
\hline 15 & 14 & 9 & Bilateral Profound & - & c.35delG & p.Gly12ValfsTer2 & Homo. & $\begin{array}{l}\text { Parents are } \\
\text { heterozygous } \\
\text { for each of the } \\
\text { mutations. }\end{array}$ & $\begin{array}{l}\text { Pathogenic } \\
\text { (Pathogenic/Pathogenic) }\end{array}$ \\
\hline 40 & 25 & 7 & Bilateral Profound & Right & c.35delG & p.Gly12ValfsTer2 & Homo. & & $\begin{array}{l}\text { Pathogenic } \\
\text { (Pathogenic/Pathogenic) }\end{array}$ \\
\hline 45 & 30 & 12 & $\begin{array}{l}\text { Right Moderately } \\
\text { Severe/Left Severe }\end{array}$ & - & c.35delG & p.Gly12ValfsTer2 & Homo. & $\begin{array}{l}\text { Parents are } \\
\text { heterozygous } \\
\text { for each of the } \\
\text { mutations. }\end{array}$ & $\begin{array}{l}\text { Pathogenic } \\
\text { (Pathogenic/Pathogenic) }\end{array}$ \\
\hline 60 & 39 & 12 & $\begin{array}{l}\text { Right Moderate/ } \\
\text { Left Moderately } \\
\text { Severe }\end{array}$ & - & c.35delG & p.Gly12ValfsTer2 & Homo. & $\begin{array}{l}\# 60 \text { and \#61 } \\
\text { are sibs. Both } \\
\text { have SNHL. }\end{array}$ & $\begin{array}{l}\text { Pathogenic } \\
\text { (Pathogenic/Pathogenic) }\end{array}$ \\
\hline 61 & 39 & 16 & $\begin{array}{l}\text { Right Moderately } \\
\text { Severe/Left Severe }\end{array}$ & - & c. $35 \mathrm{delG}$ & p.Gly12ValfsTer2 & Homo. & $\begin{array}{l}\# 60 \text { and \#61 } \\
\text { are sibs. Both } \\
\text { have SNHL. }\end{array}$ & $\begin{array}{l}\text { Pathogenic } \\
\text { (Pathogenic/Pathogenic) }\end{array}$ \\
\hline 62 & 40 & 7 & Bilateral Profound & Right & c.35delG & p.Gly12ValfsTer2 & Homo. & & $\begin{array}{l}\text { Pathogenic } \\
\text { (Pathogenic/Pathogenic) }\end{array}$ \\
\hline 66 & 44 & 30 & NDA & - & c.35delG & p.Gly12ValfsTer2 & Homo. & $\begin{array}{l}\# 66 \text { and \#79 } \\
\text { are sibs. Both } \\
\text { have SNHL. }\end{array}$ & $\begin{array}{l}\text { Pathogenic } \\
\text { (Pathogenic/Pathogenic) }\end{array}$ \\
\hline 79 & 44 & 28 & NDA & - & c.35delG & p.Gly12ValfsTer3 & Homo. & $\begin{array}{l}\# 66 \text { and \#79 } \\
\text { are sibs. Both } \\
\text { have SNHL. }\end{array}$ & $\begin{array}{l}\text { Pathogenic } \\
\text { (Pathogenic/Pathogenic) }\end{array}$ \\
\hline 68 & 46 & 14 & NDA & Right/Left & c.35delG & p.Gly12ValfsTer2 & Homo. & & $\begin{array}{l}\text { Pathogenic } \\
\text { (Pathogenic/Pathogenic) }\end{array}$ \\
\hline 69 & 48 & 5 & $\begin{array}{l}\text { Bilateral } \\
\text { Moderately severe }\end{array}$ & Right/Left & c.35delG & p.Gly12ValfsTer2 & Homo. & $\begin{array}{l}\text { Parents are } \\
\text { heterozygous } \\
\text { for each of the } \\
\text { mutations. }\end{array}$ & $\begin{array}{l}\text { Pathogenic } \\
\text { (Pathogenic/Pathogenic) }\end{array}$ \\
\hline 87 & 57 & 1 & Bilateral Profound & - & c.35delG & p.Gly12ValfsTer2 & Homo. & & $\begin{array}{l}\text { Pathogenic } \\
\text { (Pathogenic/Pathogenic) }\end{array}$ \\
\hline 88 & 58 & 9 & Bilateral Profound & Right & c.35delG & p.Gly12ValfsTer2 & Homo. & $\begin{array}{l}\text { Parents are } \\
\text { heterozygous } \\
\text { for each of the } \\
\text { mutations. }\end{array}$ & $\begin{array}{l}\text { Pathogenic } \\
\text { (Pathogenic/Pathogenic) }\end{array}$ \\
\hline 106 & 65 & 47 & Bilateral Moderate & - & c.35delG & p.Gly12ValfsTer2 & Homo. & & $\begin{array}{l}\text { Pathogenic } \\
\text { (Pathogenic/Pathogenic) }\end{array}$ \\
\hline 101 & 66 & 21 & $\begin{array}{l}\text { Bilateral Moderately } \\
\text { severe }\end{array}$ & - & c.35delG & p.Gly12ValfsTer2 & Homo. & & $\begin{array}{l}\text { Pathogenic } \\
\text { (Pathogenic/Pathogenic) }\end{array}$ \\
\hline 102 & 67 & 7 & Bilateral Profound & Right & c.35delG & p.Gly12ValfsTer2 & Homo. & $\begin{array}{l}\text { Parents are } \\
\text { heterozygous for } \\
\text { each of the } \\
\text { mutations. }\end{array}$ & $\begin{array}{l}\text { Pathogenic } \\
\text { (Pathogenic/Pathogenic) }\end{array}$ \\
\hline 115 & 74 & 4 & Bilateral Profound & Right/Left & c.35delG & p.Gly12ValfsTer2 & Homo. & $\begin{array}{l}\text { Parents are } \\
\text { heterozygous for } \\
\text { each of the } \\
\text { mutations. }\end{array}$ & $\begin{array}{l}\text { Pathogenic } \\
\text { (Pathogenic/Pathogenic) }\end{array}$ \\
\hline 122 & 78 & 35 & NDA & - & c.35delG & p.Gly12ValfsTer2 & Homo. & & $\begin{array}{l}\text { Pathogenic } \\
\text { (Pathogenic/Pathogenic) }\end{array}$ \\
\hline 126 & 82 & 28 & Bilateral Profound & - & c.35delG & p.Gly12ValfsTer2 & Homo. & $\begin{array}{l}\text { Mother (\#126), } \\
\text { father (\#127) and } \\
\text { daughter (\#133) } \\
\text { are homozygous }\end{array}$ & $\begin{array}{l}\text { Pathogenic } \\
\text { (Pathogenic/Pathogenic) }\end{array}$ \\
\hline
\end{tabular}


Table 1. Patients' age, degree of hearing loss, molecular genetic findings and results of family investigations (continued)

\begin{tabular}{|c|c|c|c|c|c|c|c|c|c|}
\hline Patient \# & Family\# & Age & $\begin{array}{l}\text { Degree of } \\
\text { SNHL }\end{array}$ & $\begin{array}{l}\text { Cochlear } \\
\text { implant }\end{array}$ & $\begin{array}{l}\text { GJB2 } \\
\text { variant }\end{array}$ & $\begin{array}{l}\text { Protein } \\
\text { Change }\end{array}$ & Status & $\begin{array}{l}\text { Family } \\
\text { Investigations }\end{array}$ & $\begin{array}{l}\text { Variant Interpret. } \\
\text { (ACMG/ClinVar) }\end{array}$ \\
\hline 127 & 82 & 30 & Bilateral Profound & - & c.35delG & p.Gly12ValfsTer2 & Homo. & $\begin{array}{l}\text { Mother (\#126), } \\
\text { father (\#127) and } \\
\text { daughter (\#133) } \\
\text { are homozygous }\end{array}$ & $\begin{array}{l}\text { Pathogenic } \\
\text { (Pathogenic/Pathogenic) }\end{array}$ \\
\hline 133 & 82 & 4 & Bilateral Profound & - & c. $35 \mathrm{delG}$ & p.Gly12ValfsTer2 & Homo. & $\begin{array}{l}\text { Mother (\#126), } \\
\text { father (\#127) and } \\
\text { daughter (\#133) } \\
\text { are homozygous }\end{array}$ & $\begin{array}{l}\text { Pathogenic } \\
\text { (Pathogenic/Pathogenic) }\end{array}$ \\
\hline 137 & 89 & 9 & $\begin{array}{l}\text { Right Moderate/ } \\
\text { Left Severe }\end{array}$ & - & c. $35 \mathrm{del} G$ & p.Gly12ValfsTer2 & Homo. & $\begin{array}{l}\# 137 \text { and } \# 138 \\
\text { are sibs. Both } \\
\text { have SNHL. }\end{array}$ & $\begin{array}{l}\text { Pathogenic } \\
\text { (Pathogenic/Pathogenic) }\end{array}$ \\
\hline 138 & 89 & 4 & Bilateral Severe & - & c. $35 \mathrm{delG}$ & p.Gly12ValfsTer2 & Homo. & $\begin{array}{l}\# 137 \text { and \#138 } \\
\text { are sibs. Both } \\
\text { have SNHL. }\end{array}$ & $\begin{array}{l}\text { Pathogenic } \\
\text { (Pathogenic/Pathogenic) }\end{array}$ \\
\hline 146 & 95 & $?$ & Bilateral Profound & Right & c. $35 \mathrm{delG}$ & p.Gly12ValfsTer2 & Homo. & $\begin{array}{l}\text { Parents are } \\
\text { heterozygous for } \\
\text { each of the } \\
\text { mutations. }\end{array}$ & $\begin{array}{l}\text { Pathogenic } \\
\text { (Pathogenic/Pathogenic) }\end{array}$ \\
\hline 151 & 97 & 4 & Bilateral Profound & Right/Left & c. $35 \mathrm{delG}$ & p.Gly12ValfsTer2 & Homo. & $\begin{array}{l}\text { Parents are } \\
\text { heterozygous for } \\
\text { each of the } \\
\text { mutations. }\end{array}$ & $\begin{array}{l}\text { Pathogenic } \\
\text { (Pathogenic/Pathogenic) }\end{array}$ \\
\hline 182 & 111 & 24 & Bilateral Profound & - & c. $35 \mathrm{delG}$ & p.Gly12ValfsTer2 & Homo. & & $\begin{array}{l}\text { Pathogenic } \\
\text { (Pathogenic/Pathogenic) }\end{array}$ \\
\hline \multirow[t]{2}{*}{18} & 11 & 5 & \multirow[t]{2}{*}{$\begin{array}{l}\text { Right Severe/ } \\
\text { Left Moderate }\end{array}$} & - & c. $35 \mathrm{delG}$ & p.Gly12ValfsTer2 & $\begin{array}{l}\text { Comp. } \\
\text { Het. }\end{array}$ & \multirow{2}{*}{$\begin{array}{l}\text { Parents are } \\
\text { heterozygous for } \\
\text { each of the } \\
\text { mutations. }\end{array}$} & $\begin{array}{l}\text { Pathogenic } \\
\text { (Pathogenic/Pathogenic) }\end{array}$ \\
\hline & & & & & c. $47 \mathrm{~A}>\mathrm{G}$ & p.His16Arg & $\begin{array}{l}\text { Comp. } \\
\text { Het. }\end{array}$ & & $\begin{array}{l}\text { Pathogenic } \\
\text { (Pathogenic/Pathogenic) }\end{array}$ \\
\hline \multirow[t]{2}{*}{43} & 28 & 5 & \multirow[t]{2}{*}{$\begin{array}{l}\text { Bilateral Moderately } \\
\text { severe }\end{array}$} & - & c.35delG & p.Gly12ValfsTer2 & $\begin{array}{l}\text { Comp. } \\
\text { Het. }\end{array}$ & & $\begin{array}{l}\text { Pathogenic } \\
\text { (Pathogenic/Pathogenic) }\end{array}$ \\
\hline & & & & - & c. $269 \mathrm{~T}>\mathrm{C}$ & p.Leu90Pro & $\begin{array}{l}\text { Comp. } \\
\text { Het. }\end{array}$ & & $\begin{array}{l}\text { Pathogenic } \\
\text { (VUS/Pathogenic) }\end{array}$ \\
\hline \multirow[t]{2}{*}{166} & 110 & 2 & \multirow[t]{2}{*}{ Bilateral Moderate } & - & c. $35 \mathrm{delG}$ & p.Gly12ValfsTer2 & $\begin{array}{l}\text { Comp. } \\
\text { Het. }\end{array}$ & \multirow[t]{2}{*}{$\begin{array}{l}\# 166 \text { and \#167 } \\
\text { are sibs. Both } \\
\text { have SNHL. }\end{array}$} & $\begin{array}{l}\text { Pathogenic } \\
\text { (Pathogenic/Pathogenic) }\end{array}$ \\
\hline & & & & - & c. $71 \mathrm{G}>\mathrm{A}$ & p.Trp24Ter & $\begin{array}{l}\text { Comp. } \\
\text { Het. }\end{array}$ & & $\begin{array}{l}\text { Pathogenic } \\
\text { (Pathogenic/Pathogenic) }\end{array}$ \\
\hline \multirow[t]{3}{*}{167} & 110 & 3 & Bilateral Moderate & - & c.35delG & p.Gly12ValfsTer2 & $\begin{array}{l}\text { Comp. } \\
\text { Het. }\end{array}$ & \multirow[t]{2}{*}{$\begin{array}{l}\# 166 \text { and \#167 } \\
\text { are sibs. Both } \\
\text { have SNHL. }\end{array}$} & $\begin{array}{l}\text { Pathogenic } \\
\text { (Pathogenic/Pathogenic) }\end{array}$ \\
\hline & & & & - & c. $71 \mathrm{G}>\mathrm{A}$ & p.Trp24Ter & $\begin{array}{l}\text { Comp. } \\
\text { Het. }\end{array}$ & & $\begin{array}{l}\text { Pathogenic } \\
\text { (Pathogenic/Pathogenic) }\end{array}$ \\
\hline & & & & & c. $457 \mathrm{G}>\mathrm{A}$ & & & & \\
\hline 5 & 2 & 8 & Bilateral Moderate & - & c. $457 \mathrm{G}>\mathrm{A}$ & p.Val153Ile & Het. & & Benign (VUS/Benign) \\
\hline 14 & 8 & 6 & $\begin{array}{l}\text { Bilateral } \\
\text { Moderately } \\
\text { severe }\end{array}$ & - & c. $457 \mathrm{G}>\mathrm{A}$ & p.Val153Ile & Het. & & Benign (VUS/Benign) \\
\hline 65 & 43 & 1 & Bilateral Mild & - & c. $457 \mathrm{G}>\mathrm{A}$ & p.Val153Ile & Het. & & Benign (VUS/Benign) \\
\hline 75 & 50 & 36 & NDA & - & c. $457 \mathrm{G}>\mathrm{A}$ & p.Val153Ile & Het. & & Benign (VUS/Benign) \\
\hline 108 & 70 & 11 & $\begin{array}{l}\text { Bilateral } \\
\text { Moderately } \\
\text { severe }\end{array}$ & - & c. $457 \mathrm{G}>\mathrm{A}$ & p.Val153Ile & Het. & & Benign (VUS/Benign) \\
\hline
\end{tabular}


Özy1lmaz et al.

146 Genetics of Non-Syndromic Hearing Loss

Turk Arch Otorhinolaryngol 2019; 57(3): 140-8

Table 1. Patients' age, degree of hearing loss, molecular genetic findings and results of family investigations (continued)

\begin{tabular}{|c|c|c|c|c|c|c|c|c|c|}
\hline Patient \# & Family\# & Age & $\begin{array}{l}\text { Degree of } \\
\text { SNHL }\end{array}$ & $\begin{array}{l}\text { Cochlear } \\
\text { implant }\end{array}$ & $\begin{array}{l}\text { GJB2 } \\
\text { variant }\end{array}$ & $\begin{array}{l}\text { Protein } \\
\text { Change }\end{array}$ & Status & $\begin{array}{l}\text { Family } \\
\text { Investigations }\end{array}$ & $\begin{array}{l}\text { Variant Interpret. } \\
\text { (ACMG/ClinVar) }\end{array}$ \\
\hline & & & & & c. $487 \mathrm{~A}>\mathrm{G}$ & & & & \\
\hline 7 & 3 & 7 & $\begin{array}{l}\text { Bilateral Moderately } \\
\text { severe }\end{array}$ & - & c. $487 \mathrm{~A}>\mathrm{G}$ & p.Met163Val & Het. & $\begin{array}{l}\text { His mother } \\
\text { has the same } \\
\text { mutation, with } \\
\text { NO SNHL. }\end{array}$ & VUS (VUS/VUS) \\
\hline 10 & 13 & 11 & Bilateral Moderate & - & c. $487 \mathrm{~A}>\mathrm{G}$ & p.Met163Val & Het. & $\begin{array}{l}\text { Her mother } \\
\text { has the same } \\
\text { mutation, with } \\
\text { NO SNHL. }\end{array}$ & VUS (VUS/VUS) \\
\hline \multirow[t]{2}{*}{33} & 18 & 15 & $\begin{array}{l}\text { Right Moderate/ } \\
\text { Left Severe }\end{array}$ & - & c. $487 \mathrm{~A}>\mathrm{G}$ & p.Met163Val & Het. & & VUS (VUS/VUS) \\
\hline & & & & & c. $478 \mathrm{G}>\mathrm{A}$ & & & & \\
\hline 11 & 6 & 8 & Bilateral Moderate & - & c. $478 \mathrm{G}>\mathrm{A}$ & p.Gly160Ser & Het. & $\begin{array}{l}\# 11 \text { and \#12 } \\
\text { are sibs. Both } \\
\text { have SNHL. }\end{array}$ & VUS (VUS/VUS) \\
\hline \multirow[t]{2}{*}{12} & 6 & 6 & $\begin{array}{l}\text { Bilateral Moderately } \\
\text { severe }\end{array}$ & - & c. $478 \mathrm{G}>\mathrm{A}$ & p.Gly160Ser & Het. & $\begin{array}{l}\# 11 \text { and \#12 } \\
\text { are sibs. Both } \\
\text { have SNHL. }\end{array}$ & VUS (VUS/VUS) \\
\hline & & & & & Others & & & & \\
\hline \multirow[t]{2}{*}{2} & 1 & 7 & Bilateral Profound & - & c. $79 \mathrm{G}>\mathrm{A}$ & p.Val27Ile & Het. (cis) & \multirow[t]{2}{*}{$\begin{array}{l}\text { His mother } \\
\text { has the same } \\
\text { mutations, with } \\
\text { NO SNHL. }\end{array}$} & Benign (Benign/Benign) \\
\hline & & & & & c. $341 \mathrm{~A}>\mathrm{G}$ & p.Glu114Gly & Het. (cis) & & Benign (VUS/Benign) \\
\hline 14 & 10 & 6 & Bilateral Moderate & - & c. $670 \mathrm{~A}>\mathrm{C}$ & p.Lys224Gln & Homo. & $\begin{array}{l}\text { Parents are } \\
\text { heterozygous for } \\
\text { each of the } \\
\text { mutations. }\end{array}$ & VUS (VUS/VUS) \\
\hline 38 & 23 & 17 & NDA & - & c. $511 \mathrm{G}>\mathrm{A}$ & p.Ala171Thr & Het. & & VUS (VUS/VUS) \\
\hline 157 & 101 & 73 & NDA & - & $\begin{array}{l}\text { c.5_9 } \\
\text { delinsCAT }\end{array}$ & p.Asp2AlafsTer45 & Het. & $\begin{array}{l}\text { Palmoplantar } \\
\text { Hyperkeratosis }\end{array}$ & $\begin{array}{l}\text { Novel Pathogenic } \\
\text { (Pathogenic/-) }\end{array}$ \\
\hline 163 & 107 & 7 & NDA & - & $\begin{array}{l}\text { c.314_ } \\
\text { 329del }\end{array}$ & p.Lys105ArgfsTer2 & Het. & & $\begin{array}{l}\text { Pathogenic } \\
\text { (Pathogenic/Pathogenic) }\end{array}$ \\
\hline 177 & 109 & 1 & NDA & - & c. $263 \mathrm{C}>\mathrm{T}$ & p.Ala88Val & Het. & $\begin{array}{l}\text { Keratitis- } \\
\text { Ichthyosis- } \\
\text { Deafness } \\
\text { syndrome (KID) }\end{array}$ & $\begin{array}{l}\text { Pathogenic } \\
\text { (L.Pathogenic/Pathogenic) }\end{array}$ \\
\hline \multirow[t]{2}{*}{135} & 87 & 7 & $\begin{array}{l}\text { Bilateral Moderately } \\
\text { severe }\end{array}$ & - & c. $551 \mathrm{G}>\mathrm{C}$ & p.Arg184Pro & Het. & & $\begin{array}{l}\text { Pathogenic } \\
\text { (VUS/Pathogenic) }\end{array}$ \\
\hline & & & & & MLPA & & & & \\
\hline 92 & 60 & 5 & Bilateral Profound & Left & WT & - & - & & $\begin{array}{l}\text { Hemizygous deletion } \\
\text { POU3F4 }\end{array}$ \\
\hline
\end{tabular}

Het: Heterozygous; Homo: Homozygous; SNHL: Sensorineural hearing loss; NDA: No data available; VUS: Variant of unknown significance

One or more GJB2 sequence variants were detected in 46 (44.2\%) of the 104 index patients. Among them, 33 (31.7\%) had pathogenic/likely pathogenic variants:

\section{Homozygous and compound heterozygous pathogenic variants}

In $25(24 \%)$ index patients, homozygous c.35delG was detected and it was the most frequent variant. This covered $75.7 \%$ of all GJB2 associated pathogenic/likely Pathogenic variants. In the GJB2 gene, most of the pathologic mutations are located in exon 2, and the c.35delG mutation in this exon is the most frequent cause of NSHL in Turkey and in the world (15). Atik et al. (16) investigated the role of GJB2 and Mendelian exome sequencing panel in ARNSHL, and found $24.13 \%$ GJB2 associated homozygous or compound heterozygous causative mutations. Tekin et al. (12) reported that they have found the c.35delG allele in $68(22.1 \%)$ of 308 chromosomes. With our data and previously reported ratios, we suggest that c.35delG mutation alone explains around 25\% of the etiology in the ARSNHL group. Of the 
remaining eight patients with pathogenic/likely pathogenic variants, four patients were carrying pathogenic/likely pathogenic variants in (compound) heterozygous state along with c. $35 \mathrm{delG}$ (c.35delG/ c. $47 \mathrm{~A}>\mathrm{G}$, c.35delG/ c. $269 \mathrm{~T}>\mathrm{C}$, c. $35 \mathrm{delG} /$ c. $71 \mathrm{G}>\mathrm{A}$ ). The c. $47 \mathrm{~A}>\mathrm{G}$, c. $269 \mathrm{~T}>\mathrm{C}$ and c. $71 \mathrm{G}>\mathrm{A}$ mutations were previously reported pathogenic variants that were associated with ARNSHL.

\section{Heterozygous pathogenic variants}

Four patients were carrying the c.5_9delinsCAT, c.314_329del, c. $263 \mathrm{C}>\mathrm{T}$ and c. $551 \mathrm{G}>\mathrm{C}$ variants in heterozygous state. In GJB2, variants detected in heterozygote state often create controversy in terms of the probability of autosomal dominant inheritance. The literature and databases were investigated against the probability that these variants were autosomal dominant. The heterozygous c.5_9delinsCAT variant was detected in a patient with hearing loss and palmoplantar hyperkeratosis (\#157). The variant was not listed in databases. It was causing a frameshift and it was interpreted as "likely pathogenic" according to the ACMG guideline (PVS1, PM2, PM2). Since it was not previously reported and family data were not available, it is not possible to determine whether this variant is a dominant or a recessive mutation. However, we report this variant as a novel pathogenic mutation. The c.314_329del (p.Lys105ArgfsTer2) variant was found in patient \#163 in heterozygous form. It was listed as pathogenic and associated with autosomal recessive SNHL in ClinVar. However, another mutation in the same amino acid position (c.313_326del [p.Lys105GlyfsTer5]) was reported to be associated with both autosomal recessive and autosomal dominant SNHL (17). Thus, we suggest that this variant in our patient may be causing autosomal dominant SNHL. The c.263C > T was detected in patient \#177 in heterozygous state. The variant was a previously known pathogenic mutation. It was previously associated with keratitis-ichthyosis-deafness (KID) syndrome in heterozygous state and suggested that the c. $263 \mathrm{C}>\mathrm{T}$ mutation produced enhanced hemichannel activity, resulting in accelerated cell death that explains the etiology of the KID syndrome (16). In our patient the c. $551 \mathrm{G}>\mathrm{C}$ variant was also listed as pathogenic and associated with ARNSHL in ClinVar. This mutation was previously reported in the heterozygous state in NSHL patients $(18,19)$. Additionally, another mutation in the same nucleotide position (c.551G>A [p.Arg184Gln]) is associated with autosomal dominant SNHL. Again, we suggest that the c.551G $>\mathrm{C}$ variant in our patient may be associated with autosomal dominant SNHL.

\section{Variants of unknown significance (VUS)}

The four variants (c. $487 \mathrm{~A}>\mathrm{G}, \quad$ c. $478 \mathrm{G}>\mathrm{A}, \quad$ c. $670 \mathrm{~A}>\mathrm{C}$, c. $511 \mathrm{G}>\mathrm{A}$ ) which were detected in seven patients, were reported as VUS in databases. The c. $487 \mathrm{~A}>\mathrm{G}$ variant found in patients \#7, \#10 and \#33, was previously identified in patients with NSHL in heterozygous state $(19,20)$. Further, Falah et al. (20) reported two families with this variant and suggested that the variant may lead to autosomal dominant effect. Moreover, two other missense variants at the same position (p.Met163Leu and p.Met163Thr) have been reported as pathogenic/likely pathogenic in the ClinVar database (21). Based on our and the previous literature data, we suggest that this variant may have clinical effects with autosomal dominant inheritance. The c. $478 \mathrm{G}>\mathrm{A}$ variant was found in two sibs (\#11 and \#12) with NSHL. Zheng et al. (22) reported two patients in whom the c. $478 \mathrm{G}>\mathrm{A}$ variant was found to be in cis with a known pathogenic variant. In addition, this variant was reported in controls in other populations. These data strongly support the benign nature of this variant. Patient $\# 14$ was carrying homozygous c. $670 \mathrm{~A}>\mathrm{C}$ variant. This variant was previously detected in heterozygous form in NSHL patients and the pathogenic effect was not concluded (22). In our patient, however, it was detected in homozygous state, and parents were carriers. As a result, the clinical significance of the c. $670 \mathrm{~A}>\mathrm{C}$ variant is still uncertain. The c. $511 \mathrm{G}>\mathrm{A}$ variant was detected in patient \#135 in heterozygous state. The variant was previously identified in two individuals with normal hearing (22). Thus, we suggest that the effect of this variant is controversial.

\section{Copy number changes}

Although the point mutations cover most of the genetic defects in ARSNHL, copy number changes were also identified (23). In Patient \#5, a hemizygous deletion covering the POU3F4 gene was detected. Microdeletions covering the POU $3 F 4$ gene have been described as causative for the most common form of X-linked NSHL (24). In one (5\%) of the 20 patients analyzed with MLPA, we detected a deletion. This data contributes to the role of copy number changes in NSHL etiology.

\section{Patients with no variants and patients with benign variants}

In the 58 patients with no variants and six patients with benign variants, the molecular genetic etiology remained unsolved. Additional molecular genetic studies should be planned for these 64 patients and even for the seven patients with VUS. We suggest that this second step approach can be carried out with multigene next-generation sequencing (NGS) panels or with whole exome/genome sequencing (WES/WGS).

\section{Clinical diversity}

The clinical effects of $\mathrm{Cx} 26$ mutations are associated with hearing the loss at different levels of severity. However, mutations can also cause deafness associated with skin diseases. Furthermore, these skin diseases are associated with specific mutations in the same gene. Shuja et al. (25) suggested that unique channel activities are influenced by each class of mutation. In this report, we present two patients with additional skin diseases. Patient \#157 had hearing loss and palmoplantar hyperkeratosis and patient \#177 was diagnosed with keratitis-ichthyosis-deafness (KID) syndrome. 


\section{Conclusion}

In this Turkish cohort of 104 index patients and 78 relatives, $33(31.7 \%)$ had pathogenic/likely pathogenic variants. The homozygous c.35delG mutation alone explained $24 \%$ of the etiology in our ARSNHL group. Distinct mutations in Cx26 can cause deafness associated with skin diseases. As an example of these patients, we reported two patients with deafness with palmoplantar hyperkeratosis and KID syndrome.

Ethics Committee Approval: Ethics committee approval was received for this study from University of Health Sciences, Tepecik Training and Research Hospital (2019/2-18).

Informed Consent: Written informed consent was obtained from the parents of the patients.

Peer-review: Externally peer-reviewed.

Author Contributions: Concept - B.Ö., G.C.M.; Design - B.Ö., G.C.M.; Supervision - B.Ö., G.C.M.; Resource - B.Ö.,Ö.K., T.R.Ö., Ö.Ö.K., Y.B.K., K.M.E., M.S.G., A.K.; Materials - B.Ö., G.C.M., S.Ö.; Data Collection and/or Processing - B.Ö., S.Ö.; Analysis and/ or Interpretation - B.Ö., Ö.K., T.R.Ö., Ö.Ö.K., Y.B.K., K.M.E., M.S.G., A.K.; Literature Search - B.Ö., S.Ö.; Writing - B.Ö., G.C.M.; Critical Reviews - B.Ö., Ö.K., T.R.Ö., Ö.Ö.K., Y.B.K., K.M.E., M.S.G., A.K.

Conflict of Interest: The authors have no conflicts of interest to declare.

Financial Disclosure: The authors declared that this study has received no financial support.

\section{References}

1. WHO. Deafness and hearing loss: World Health Organization 2019 [updated 03.2019; cited 2019 08.20.2019]. Available from: URL: http://www.who.int/mediacentre/factsheets/fs300/en/.

2. WHO.WHO global estimates on prevalence of hearing loss 2012 [updated 2012; cited 2019 20.08.2019]. Mortality and Burden of Diseases and Prevention of Blindness and Deafness]. Available from: https://www.who.int/pbd/deafness/WHO_GE_HL.pdf.

3. Paludetti G, Conti G, Di Nardo W, De Corso E, Rolesi R, Picciotti P, et al. Infant hearing loss: from diagnosis to therapy Official Report of XXI Conference of Italian Society of Pediatric Otorhinolaryngology. Acta Otorhinolaryngologica Italica 2012; 32: 347.

4. ASHA. Configuration of Hearing Loss: American Speech-Language-Hearing Association; [cited 2018 01.15.2018]. Available from: URL: http://www.asha.org/public/hearing/Configuration-of-Hearing-Loss/.

5. Yan D, Tekin D, Bademci G, Foster J, Cengiz FB, Kannan-Sundhari A, et al. Spectrum of DNA variants for non-syndromic deafness in a large cohort from multiple continents. Human genetics 2016; 135: 953-61. [CrossRef]

6. Shearer AE, DeLuca AP, Hildebrand MS, Taylor KR, Gurrola $\mathrm{J}$, Scherer $\mathrm{S}$, et al. Comprehensive genetic testing for hereditary hearing loss using massively parallel sequencing. Proc Natl Acad Sci U S A 2010; 107: 21104-9. [CrossRef]

7. Nonsyndromic hearing loss NIH2019 [updated 01.2019; cited 2019 27.01]. Available from: URL: https://ghr.nlm.nih.gov/condition/nonsyndromic-hearing-loss\#inheritance.

8. Venkatesh M, Moorchung N, Puri B. Genetics of non syndromic hearing loss. Med J Armed Forces India 2015; 71: 363-8. [CrossRef]
9. Wang HL, Chang WT, Li AH, Yeh TH, Wu CY, Chen MS, et al. Functional analysis of connexin-26 mutants associated with hereditary recessive deafness. J Neurochem 2003; 84: 735-42. [CrossRef]

10. Angeli S, Lin X, Liu XZ. Genetics of hearing and deafness. Anat Rec (Hoboken) 2012; 295: 1812-29. [CrossRef]

11. Liming BJ, Carter J, Cheng A, Choo D, Curotta J, Carvalho D, et al. International Pediatric Otolaryngology Group (IPOG) consensus recommendations: Hearing loss in the pediatric patient. Int J Pediatr Otorhinolaryngol 2016; 90: 251-8. [CrossRef]

12. Tekin M, Duman T, Boğoçlu G, İncesulu A, Çomak E, Ilhan I, et al. Spectrum of GJB2 mutations in Turkey comprises both Caucasian and Oriental variants: roles of parental consanguinity and assortative mating. Hum Mutat 2003; 21: 552-3. [CrossRef]

13. Landrum MJ, Lee JM, Benson M, Brown GR, Chao C, Chitipiralla $\mathrm{S}$, et al. ClinVar: improving access to variant interpretations and supporting evidence. Nucleic Acids Res 2017; 46(D1): D1062-D7. [CrossRef]

14. Richards S, Aziz N, Bale S, Bick D, Das S, Gastier-Foster J, et al. Standards and guidelines for the interpretation of sequence variants: a joint consensus recommendation of the American College of Medical Genetics and Genomics and the Association for Molecular Pathology. Genet Med 2015; 17: 405-24. [CrossRef]

15. Subaşıŏlu A, Duman D, Sırmacı A, Bademci G, Carkıt F, Somdaş MA, et al. Research of genetic bases of hereditary non-syndromic hearing loss. Turk Pediatri Ars 2017; 52: 122-32. [CrossRef]

16. Atik T, Onay H, Aykut A, Bademci G, Kirazli T, Tekin M, et al. Comprehensive analysis of deafness genes in families with autosomal recessive nonsyndromic hearing loss. PLoS One 2015; 10: e0142154. [CrossRef]

17. ClinVar. National Center for Biotechnology Information. ClinVar; Variation ID 2110792019 [cited 08.20.2019]. Available from: RL: https:/www.ncbi.nlm.nih.gov/clinvar/docs/variation_ report/.

18. Baysal E, Bayazit YA, Ceylaner S, Alatas N, Donmez B, Ceylaner $\mathrm{G}$, et al. GJB2 and mitochondrial $\mathrm{A} 1555 \mathrm{G}$ gene mutations in nonsyndromic profound hearing loss and carrier frequencies in healthy individuals. J Genet 2008; 87: 53-7. [CrossRef]

19. Iliades T, Eleftheriades N, Iliadou V, Pampanos A, Voyiatzis N, Economides J, et al. Prelingual nonsyndromic hearing loss in Greece. ORL J Otorhinolaryngol Relat Spec 2002; 64: 321-3. [CrossRef]

20. Falah M, Houshmand M, Mahmoudian S, Emamdjomeh H, Ghavami Y, Farhadi M. The anticipation and inheritance pattern of c. 487A> G mutation in the GJB2 gene. Arch Iran Med 2012; 15: 49-51.

21. ClinVar. National Center for Biotechnology Information. ClinVar; Variation ID 4248542019 [cited 08.20.2019]. Available from: URL: https://preview.ncbi.nlm.nih.gov/clinvar/variation/424854.

22. Zheng J, Ying Z, Cai Z, Sun D, He Z, Gao Y, et al. GJB2 mutation spectrum and genotype-phenotype correlation in $1067 \mathrm{Han} \mathrm{Chi}^{-}$ nese subjects with non-syndromic hearing loss. PloS one 2015; 10 : e0128691. [CrossRef]

23. Lerer I, Sagi M, Ben-Neriah Z, Wang T, Levi H, Abeliovich D. A deletion mutation in GJB6 cooperating with a GJB2 mutation in trans in non-syndromic deafness: a novel founder mutation in Ashkenazi Jews. Hum Mutat 2001; 18: 460. [CrossRef]

24. Song M, Lee H, Choi J, Kim S, Bok J, Kim UK. Clinical evaluation of DFN3 patients with deletions in the POU3F4 locus and detection of carrier female using MLPA. Clin Genet 2010; 78: 524-32. [CrossRef]

25. Shuja Z, Li L, Gupta S, Meşe G, White TW. Connexin26 mutations causing palmoplantar keratoderma and deafness interact with connexin43, modifying gap junction and hemichannel properties. J Invest Dermatol 2016; 136: 225-35. [CrossRef] 